\title{
URBANIZAÇÃO DE ENCOSTAS: PROJETANDO A ARQUITETURA DA PAISAGEM*
}

\section{Sonia Afonso}

Arquiteta e doutora pela Faculdade de Arquitetura e Urbanismo da Universidade de São Paulo. Professora do Departamento de Arquitetura e Urbanismo da Universidade Federal de Santa Catarina. Pesquisadora do Grupo Desenho Urbano e Paisagem do ARQ/CTC/UFSC

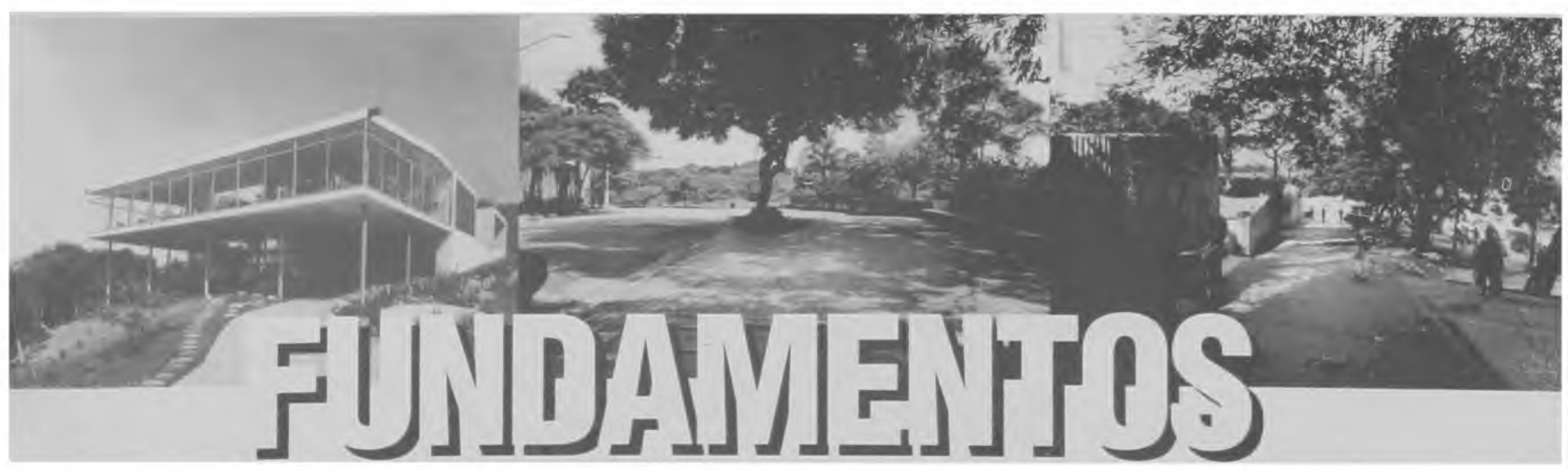




\section{RESUMO}

Ambiente e paisagem são desconsiderados no projeto das cidades brasileiras. Desde a chegada dos primeiros colonizadores europeus, cenários de serras e colinas são enaltecidos, mas a urbanização contemporânea camufla a forma dos sítios e degrada o hábitat urbano.

As encostas dos morros e serras são, por excelência, um assunto do paisagismo, pois "ninguém pode esconder uma cidade sobre uma colina" (Mt5, 14), seja para maravilhar, seja para desolar quem a observa, dependendo de quem seja.

A paisagem ambiental deveria ser composta de colinas vistas do mar e dos vales dos rios; com economia fundada nas características paisagísticas e ambientais; caracterizando-se como lugares de que nos lembraremos para sempre. Sem tal identidade não podemos dizer que uma cidade tem personalidade.

O caráter de um lugar está fundado na atitude dos que a construíram, na simpatia com que trataram seres vivos e ambiente, no valor que lhes atribuíram. O valor (ética e estética) é o aspecto filosófico da arquitetura da paisagem.

Todo projeto precisa estar comprometido com o meio físico e seus elementos: sopés, topos, ombreiras (lugares privilegiados para a construção de mirantes) e linhas de drenagem natural (locais privilegiados para a localização de parques de conservação da água), visando à preservação da biodiversidade.

\section{ABSTRACT}

Environment and landscape are not considered in the brazilian cities design. Since the first explorers arrived, sceneries of mountains and hills are exalted, but the contemporary urbanization camouflages the form of the sites and destroys the urban habitat.

The slopes of hills and mountains are, by excellence, landscape arquitecture subject: "we can not hide a city built over a hill" (M+5, 14), for good or evil, to wonder or desolate, depending on the observer.

The environmental landscape must be composed by hills and mountains seen from the sea and from the riverbeds; with the economic factors founded on the environmental and landscape features: these places will be remembered forever. Without such an identity we cannot say that a city has a landscape character.

The personality of a place is founded on the attitude of who has built it; on the sympathy they had treated living beings and the environment, in the value they attributed to it. The value (ethic and aesthetics) is the philosophic parameter of landscape architecture.

All projects must be committed to the site and its elements: lowlands, heights, prominences privileged places to locate belvederes; drainage basins - privileged places to locate water conservation parks; aiming at biological diversity. 


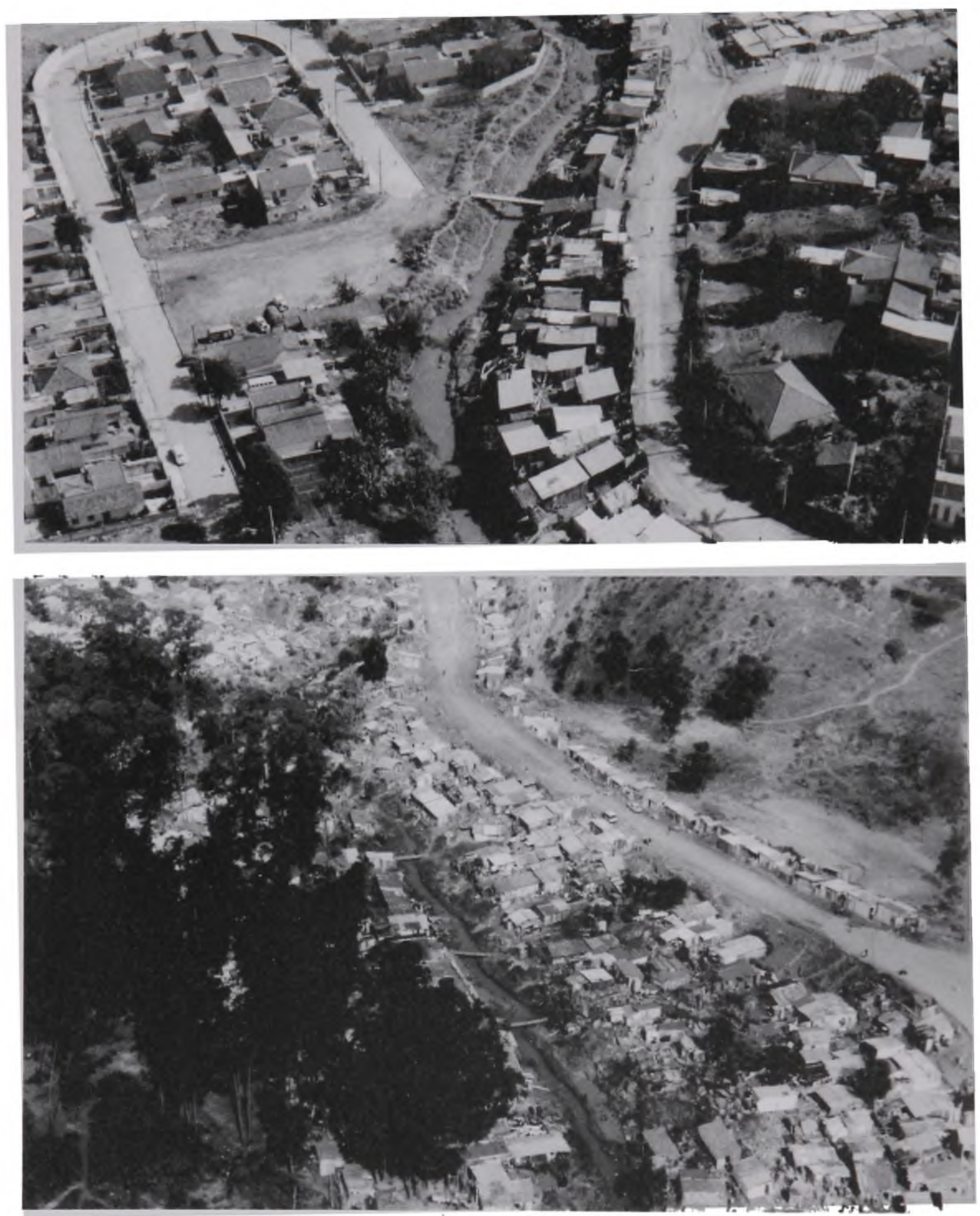

Figura 2: Paisagem da destruição: desmatamento de encostas, de margens de rios e linhas de drenagens

Em cima: Ação de desapropriação de imóveis e canalização do córrego Guaraú, pela Secretaria de Vias Públicas/ Secretaria de Negócios Jurídicos - Departamento de Desapropriações, para a abertura de avenida de fundo de vale, atendendo ao Projeto SANEGRAN, São Paulo, SP

Fonte: XI Congresso Pan-Americano de Avaliaçōes

48 Figura ao lado: Bairros-Coła, Pinhal do Miranda. Vista parcial, ocupação a jusante da via Anchieta, próxima à baixada. Ao longo da linha de drenagem natural, assinalada na foto em pontilhado (fev./84), é que se encontravam as áreas de ocupaçāo, onde ocorre a maior incidência de moradias de risco l (que demandam relocação imediata). As casas assinaladas com um círculo seriam removidas. Na área assinalada com llib seria mantido o estágio de adensamento existente. A área IVb seria desocupada e devidamente reflorestada Fonte: Relatório 20.481 IPT-SP 


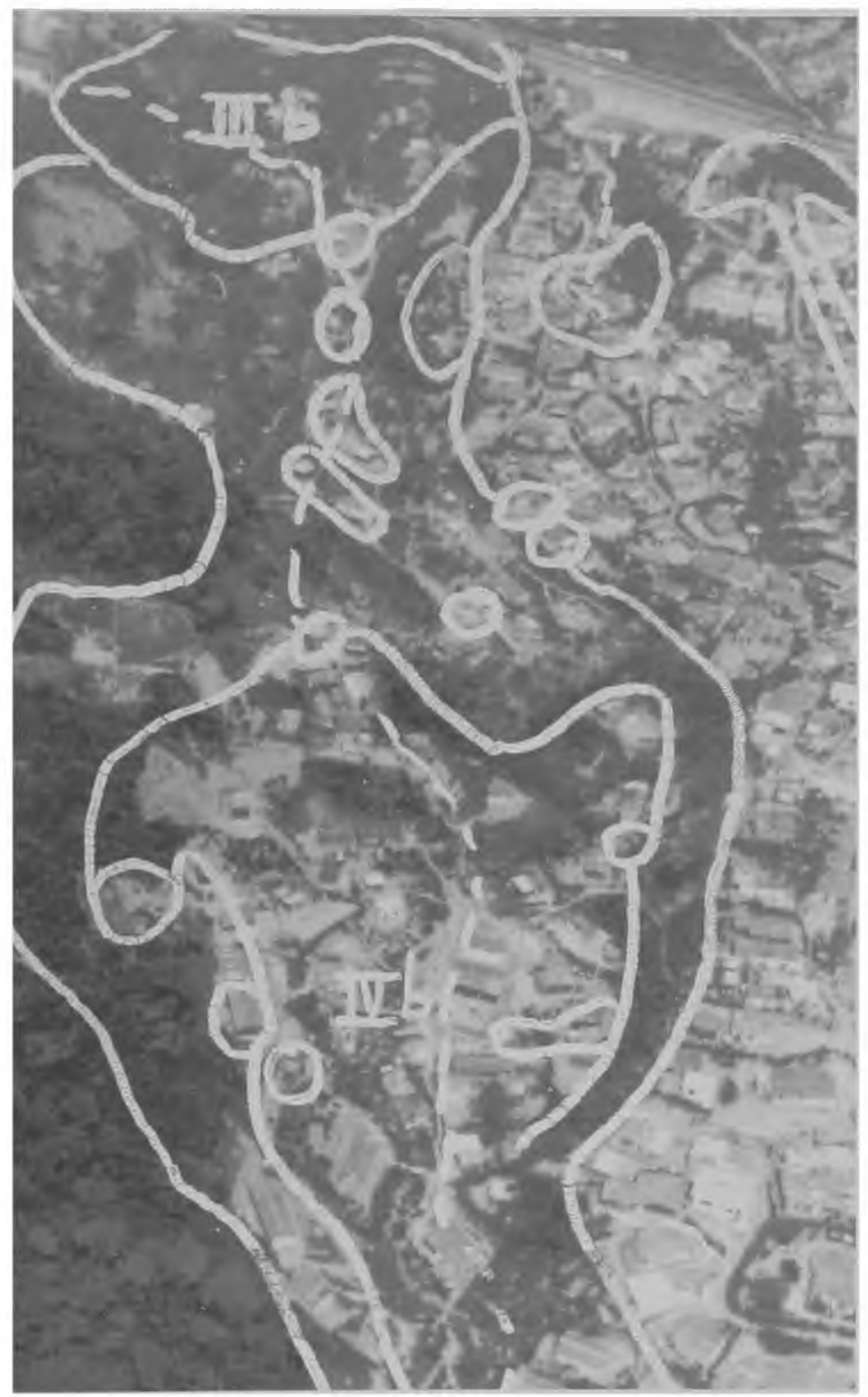

Insinuação do

Terreno Induz a

Proposta

O bairro operário de Vila Maria na região nordeste do município de São Paulo, SP, está situado na várzea do rio Tietê e ocupa colinas adjacentes, que são extensões do sopé da Serra da Cantareira, em sua porção sudeste. Colonizada por portugueses há aproximadamente um século, incorpora na nomenclatura de suas localidades mais importantes os termos Alta e Bai$x a, a$ exemplo do que ocorre em Lisboa e Salvador, que se dividem em Cidade Alta e Cidade Baixa. A Vila Maria Bai$x a$, que se estende sobre a várzea do Tietê, outrora inundável, possui sistema viário de malha ortogonal. A Vila Maria Alta, que ocupa três colinas interligadas pelo divisor de águas, entre as cotas de 750 e 800 metros, possui uma malha de ruas entrelaçadas que se acomodam ao terreno em ziguezague, de modo a vencer as declividades suavemente, como se tivessem sido traçadas em lombo de burro. Os dois vales que separam as três colinas foram destinados à implantação de áreas verdes e em dois deles efetivamente foram projetados parques e um viveiro de plantas, tudo muito singelo e de uso por vezes desvirtuado, mas de uma lógica espacial e volumétrica clara e precisa. Sobre os divisores de águas destas colinas foram lançadas ruas interceptadas por praças eqüidistantes. A forma das colinas é realçada pelas edificações de dois pavimentos uniformemente distribuídas. A relação entre a altura dos edifícios e a largura das ruas e calçadas permite a visualização do céu, transmitindo uma sensação de liberdade incomum na cidade de São Paulo. 

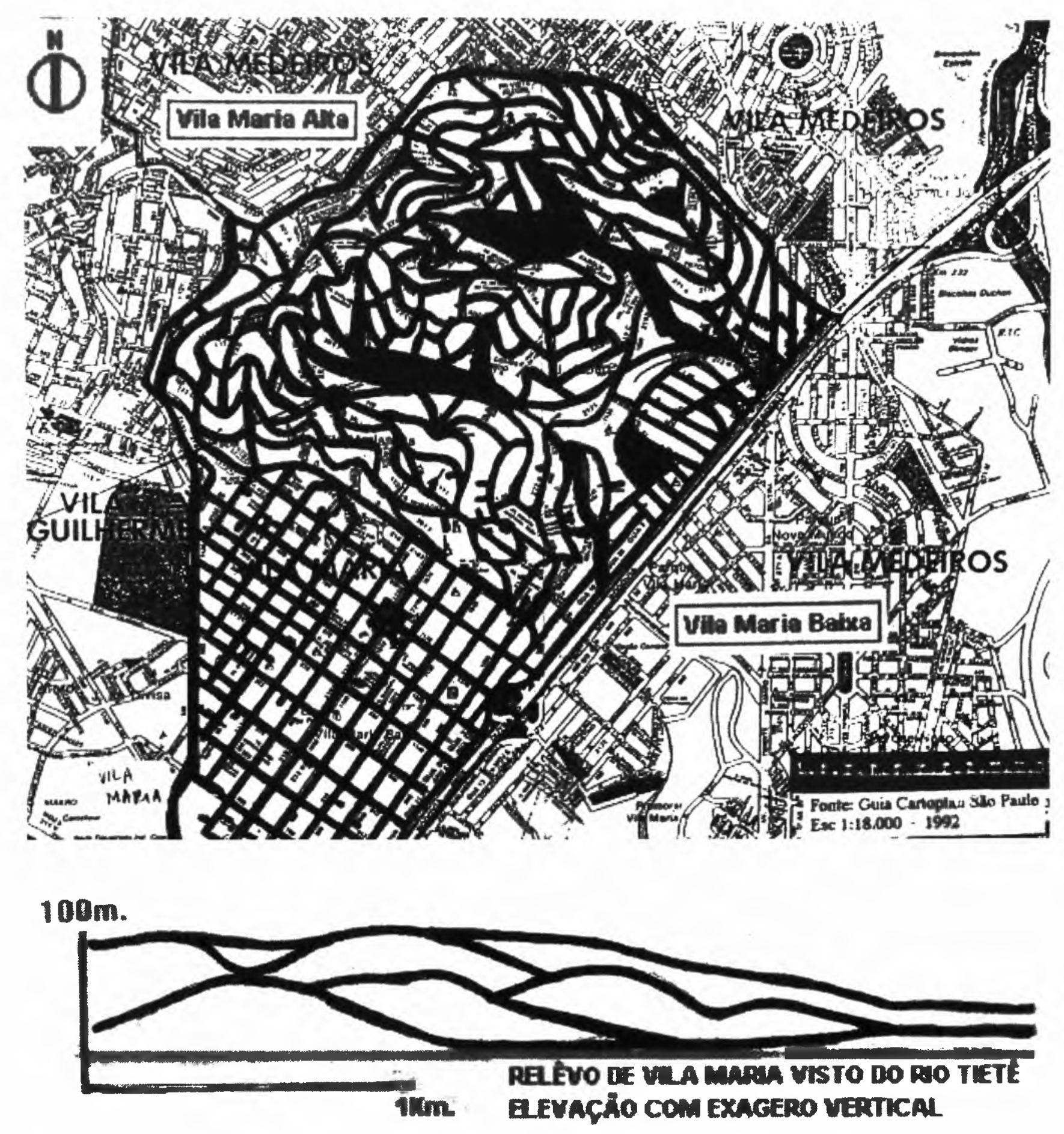

$100 \mathrm{~m}$

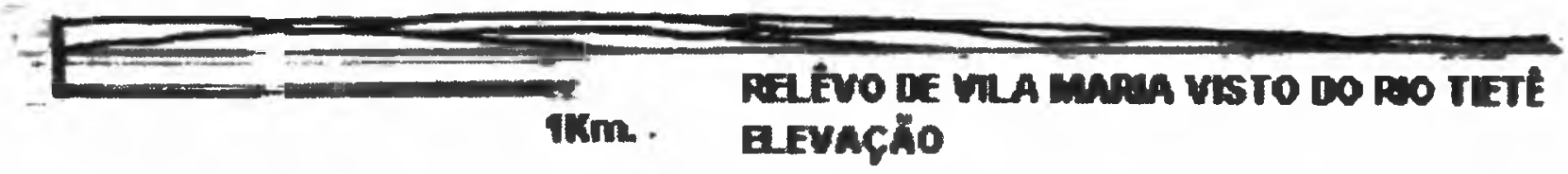

Figura 3: Malhos de espaços públicos e forma do relevo do bairro de Vila Maria

No mapa acima podemos abservar os dois tipos distintos de malhas viárias existentes no bairro de Vila Maria. Na várzea plana se percebe o modelo em grelha ortogonal e sobre as colinas foram traçadas ruas sinuosas que compõem uma malha em ziguezague. Podemos observar o sistema de espaços públicos em ambas as malhas. Este é composto por ruas, praças e parques, realçados em preto

Resumindo, o sítio físico da Vila Maria induziu a um partido urbano caracterizado por dois sistemas complementares: um sistema de praças e parques de conservação da água em fundo de vale, incluindo as cabeceiras de drenagens; e outro sistema de praças mirantes em vias de topo, ou melhor, vias sobre os divisores de águas. Acrescente- 
se a estes dois sistemas uma variedade de elementos de ligação entre níveis diferentes: ruas, praças de concordância na confluência dessas ruas e escadarias. As configurações espaciais e volumétricas da Vila Maria serviram como musas para as soluções arquitetônicas e urbanísticas que adotamos neste estudo, por considerá-las a situação mais apropriada à ocupação das encostas e dos vales. Este tipo de solução aparece como conceito entre os pesquisadores contemporâneos (Spirn, 1995 e Lyle, 1999) e pode ser encontrada em bairros nobres de São Paulo: Morumbi e Pacaembu, especialmente por meio de exemplos como as praças Vinícius de Morais e Wendel Wikie, ambas projetadas na década de 70 pelo Departamento de Parques da Prefeitura Municipal de São Paulo.

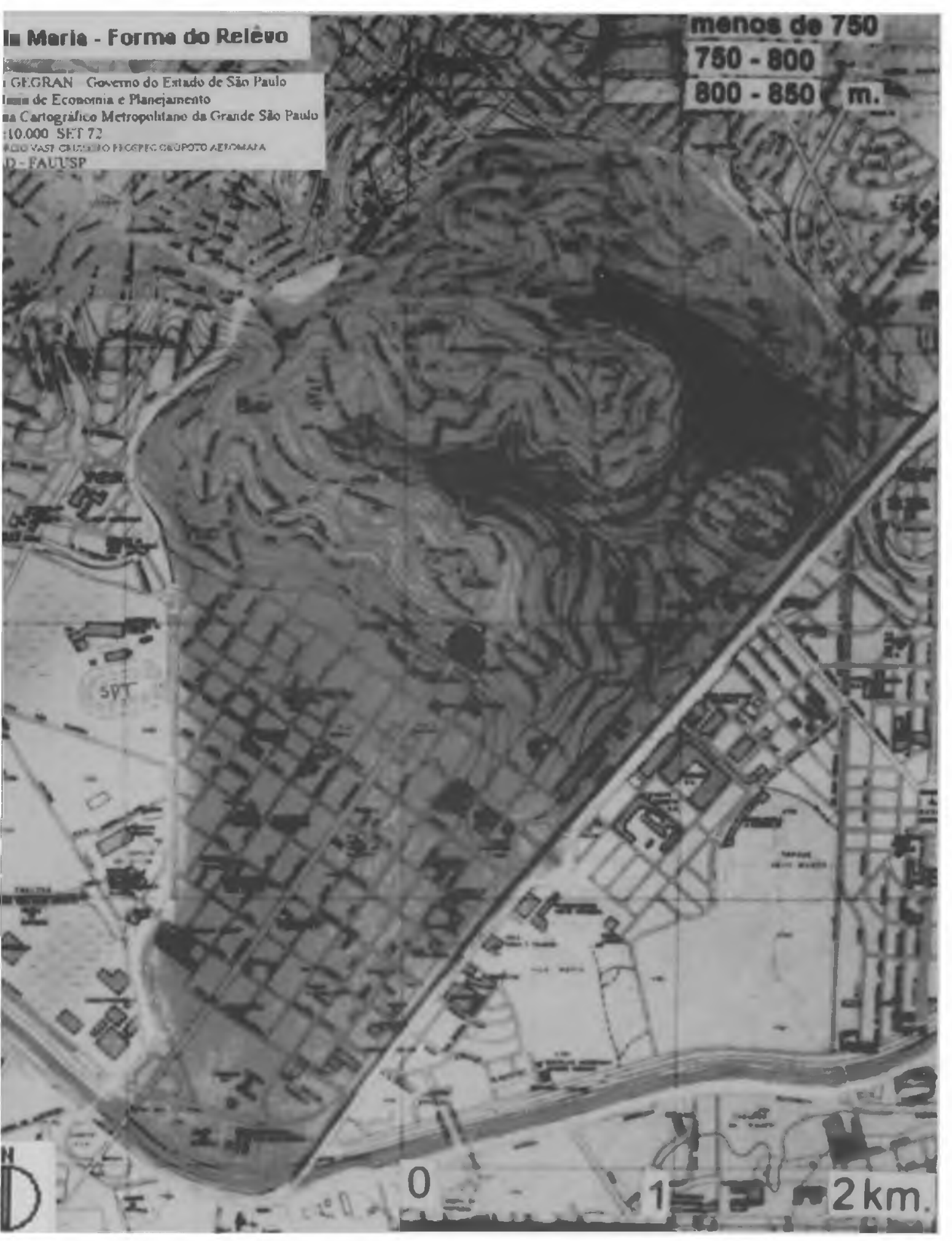

Neste mapa pode-se verificar a planta topográfica do bairro de Vila Maria, destacando a forma do seu relevo composto pelas colinas, com altitudes que variam de 750 a 800 metros e pelos vales e pela várzea do rio Tietê, situados nas cotas inferiores a 750 metros

Fonte das ilustrações: Guia Cartoplan de São Paulo, 1992 e GEGRAN, 1:10.000, 1972 


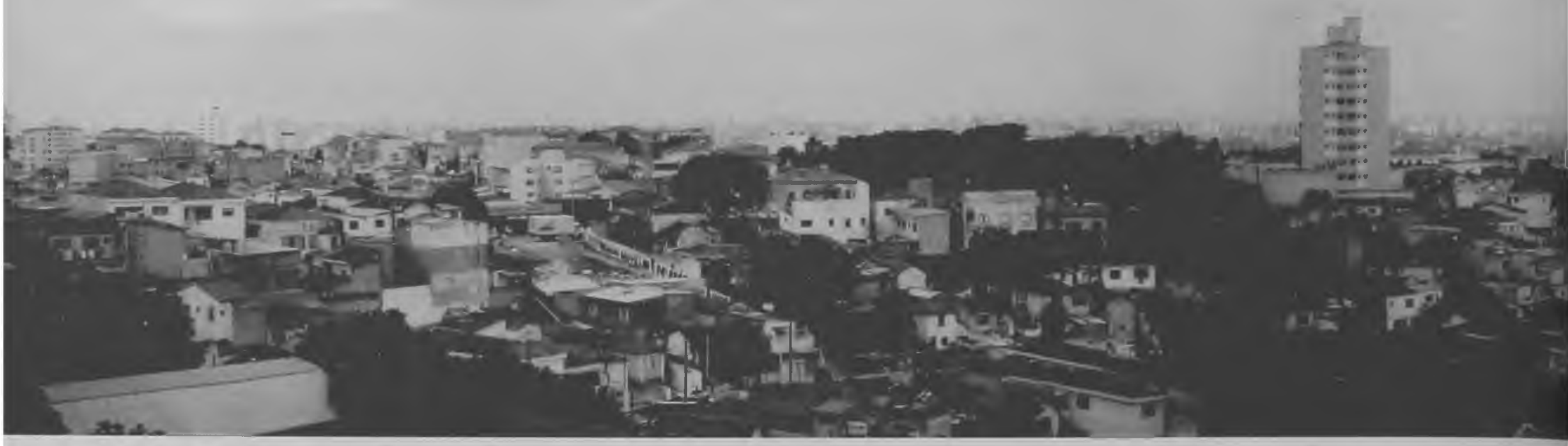

Vale do Parque Thong Mazzohi - Sul

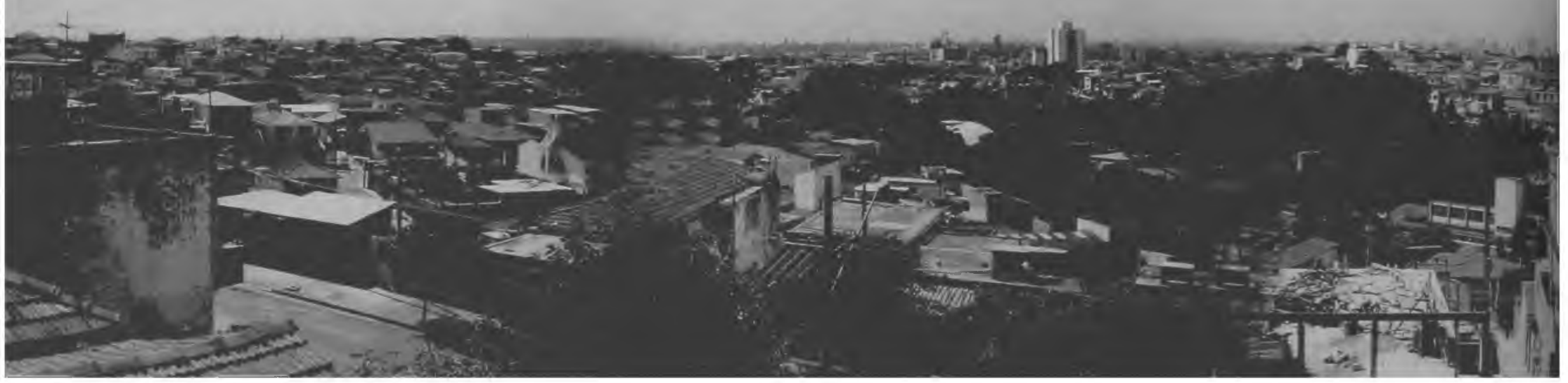

Vale da Biquinha (parte) - Nordeste

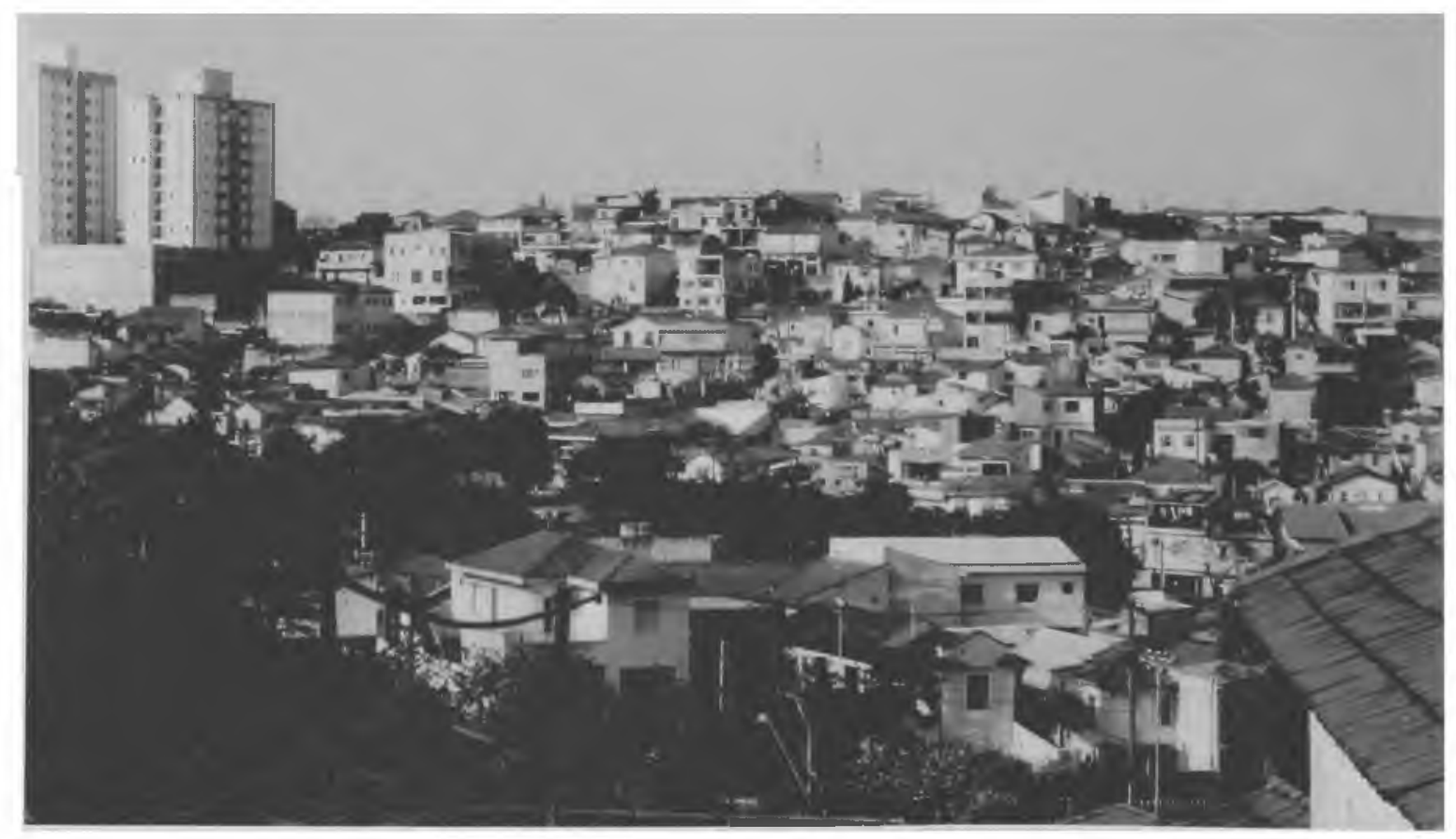

Urbanização de Encostas: Projetando a Arquitetura da Paisagem 


\section{Padrões Arquitetônicos e Urbanísticos Segundo Critérios Paisagísticos e Ambientais}

Em se tratando de planejamento urbano temos uma tendência a estudar aspectos isolados da cidade. Como exemplo, citamos os bairros tratados isoladamente pelas administrações municipais. No cotidiano urbano as decisões são tomadas de forma ainda mais fragmentada - cada construção é praticamente o resultado dos anseios do proprietário, vagamente limitados por uma legislação genérica, que raramente observa as características do meio físico. No que se refere aos municípios de uma região, as decisões são locais e pouco controladas pela legislação de instâncias superiores. Como exemplo citamos o código florestal, lei federal que, até então, tratava especialmente da proteção dos corpos d'água, pelas matas ciliares características de cada região. Na esfera municipal e especialmente no perímetro urbano este código não é observado, devido ao entendimento de que a natureza no urbano é outra. Estudos comprovam que a melhor divisão para o planejamento em diferentes escalas de abordagem, tanto regional quanto urbana, é a divisão em bacias e microbacias hidrográficas, única forma de manter uma lógica de ocupação conservacionista, com intervenções que exigem criatividade, além de um tipo de gerenciamento que supõe fiscalização e manutenção constantes.

Não existe tradição de reservar margens de rios e córregos para a conservação e para o uso como parques públicos no Brasil - algumas experiências isoladas podem ser observadas nas cidades de São Paulo e Curitiba. Entretanto, mesmo nestas cidades, estes corpos d'água têm sido transformados em avenidas e construções, sem nenhum aproveitamento paisagístico do vale e do rio. Atualmente estas linhas de drenagem estão sendo tamponadas, aterradas ou simplesmente servem para a disposição de dejetos líquidos e sólidos, contra qualquer recomendação paisagística e ambiental. $\bigcirc$ ideal seria que estas faixas de preservação integrassem um sistema de parques, sendo estas áreas arborizadas para que se efetivasse sua proteção contra as inundações. Os esgotos, separados das águas fluviais e pluviais, deveriam ser coletados e tratados para aproveitamento na lavação de ruas e rega de jardins.

Um exemplo significativo que realça, inclusive, as qualidades econô54 micas das decisões ambientais é o sistema de drenagem natural em Woodlands, no Texas, que "explora os solos com boa drenagem para absorver as águas; e os baixios arborizados e os vales de cursos d'água para escoar os aguaceiros, prevenindo desta forma as en- 
chentes rio abaixo. O uso das várzeas arborizadas existentes, como recurso de drenagem das águas pluviais, assegurou um sistema interligado de parques e trilhas através da cidade e economizou milhões de dólares" (Spirn, 1995, p. 182). Terrenos não-aproveitados podem ser "projetados como sistemas auto-regeneradores e autosustentáveis, que não apenas absorvem as águas das cheias, mas também firmam o solo instável, consenvam recursos minerais (...). Um ecossistema deste tipo pode ser criado mesmo num pequeno lote (...) e ser empregado na recuperação de terras degradadas (...). Os parques (...) urbanos devem tomar sua configuração da topografia e geologia, corpos d'água, vegetação nativa remanescente, movimento do ar e estrutura urbana construída" (Spirn, 1995, p. 274).

McHarg, (Mcharg, 1992), seguido de Lyle, Spirn e Steinitz (Lyle, 1999; Spirn, 1995; Steinitz, 1994), atribui às características sistêmicas dos terrenos uma importância preponderante no estabelecimento de diretrizes de desenvolvimento das cidades, pensando não somente nos aspectos econômicos, mas valorizando os aspectos ambientais e cênicos. Na abordagem destes autores ressaltamos a importância do uso da cartografia temática, como base de um sistema geográfico de informações para aproveitar ao máximo as condições das bacias hidrográficas, das águas subterrâneas, dos solos férteis, preservando a vegetação e a fauna existentes. Realçamos também a observação quanto à conveniência dos recursos naturais estarem localizados em terrenos públicos, para ampliar as possibilidades de um manejo controlado (Lyle, 1985, p. 138).

Com base nestes fundamentos, estabelecemos critérios e padrōes para a urbanização, em geral, e para as encostas, em particular, em estudos desenvolvidos desde o curso de mestrado (1985-1992), sob a orientação do Prof. Dr. José Cláudio Gomes, tendo por base as cartografias geotécnicas elaboradas pelo Instituto de Planejamento Urbano de Florianópolis - IPUF/PMF e pelo Instituto de Pesquisas Tecnológicas de São Paulo - IPT/SP, além das abordagens paisagísticas e ambientais aprofundadas em nosso curso de doutorado (1994-1999), especialmente pela orientação do Prof. Dr. Silvio Soares Macedo.

\section{Configuração dos Espaços Livres}

O meio físico urbano merece cuidado tanto quanto o rural; portanto, com base na observação exaustiva de dezenas de exemplos bemsucedidos, tanto no Brasil como no exterior, adotamos o seguinte método para garantir a existência de espaços livres nas intervenções urbanísticas realizadas sobre este tipo de terreno: 
- Tomamos o hectare, $10.000 \mathrm{~m}^{2}$, como sendo uma unidade espacial urbana consagrada e de fácil visualização;

- partimos do princípio que os espaços livres devem ser definidos prioritariamente na urbanização;

- estes espaços livres devem ser organizados na forma de um sistema especialmente associado às linhas de drenagens, cujas unidades estarão adaptadas às características geográficas do local;

- que a densidade de 30 domicílios por hectare, tanto em urbanização contínua como verticalizada, é uma taxa interessante, pois concilia conforto e economia. A qualidade de vida está associada às facilidades e utilidades urbanas disponíveis e à quantidade de população que pode pagar por elas, mesmo nas grandes cidades. Como exemplo citamos um estudo realizado pela New York Regional Plan Association, para a região metropolitana de Nova York, que concluiu que a densidade urbana ideal para a economia de energia elétrica é de aproximadamente 32 domicílios por hectare (Lyle, 1999, p. 240);

- que nas áreas florestadas e nas áreas com declividades superiores a $45 \%$ esta taxa deve ser de dois domicílios por hectare; por ser esta a densidade mais adequada para preservar o equilíbrio frágil das encostas acentuadas. Acreditou-se por muito tempo que destinar áreas problemáticas à preservação permanente, ou ao uso sem parcelamento, seriam as formas mais adequadas de proteção do solo e da água, por meio do controle dos desmatamentos, prejudiciais à contenção natural das encostas. Observando o desempenho de algumas dessas áreas, que acabam por ser urbanizadas de forma desordenada, pode-se concluir que o uso privado qualificado e de baixa densidade é a opção mais recente e bem-sucedida para a conservação desses terrenos em seus aspectos geotécnicos, paisagísticos e ambientais; além de permitir a multiplicação da vida silvestre (Laurie, 1983, p. 162-164). Steinitz também recomenda "conservação privada de baixa densidade" para realizar o gerenciamento biológico, ou seja, para evitar que o desenvolvimento excessivo fragmente o hábitat de espécies ameaçadas em uma região (Steinitz, 1996, p. 20). As baixíssimas densidades de conservação podem ter resultados satisfatórios, de recomposição vegetal e controle contra invasões, quando variam de 1 domicílio por $12.000 \mathrm{~m}^{2}$ até 1 domicílio por $1.250 \mathrm{~m}^{2}$, dependendo das declividades dos terrenos e dos projetos adotados (Laurie, 1983, p. 162-164). As baixas densidades não garantem a existência de espaços públicos, portanto é necessário associar o cálculo de densidades às porcentagens 
destinadas aos espaços livres públicos para a circulação, o lazer e a conservação ambiental;

- que a forma ideal de presenvar o equilíbrio das encostas é manter ou recompor a vegetação existente, por ser esta uma medida econômica e conservacionista, desde que efetivamente gerenciada;

- que a adoção arrazoada de índices de aproveitamento e taxas de ocupação dos lotes pode promover o equilíbrio entre o que é construído e o que é edificado, mas a garantia do equilíbrio paisagístico e ambiental reside em garantir pelo menos $50 \%$ dos espaços livres permeáveis e vegetados;

- que o uso misto pode ser adequado à conservação em alguns setores das encostas, desde que estes usos sejam compatíveis com a habitação. Ao mesmo tempo, deve ser dada uma solução satisfatória às necessidades de estacionamento de automóveis, evitando o impacto visual na paisagem e na estabilidade do terreno;

- que toda e qualquer intervenção sobre as encostas deve ser objeto de regulamentação, fiscalização e projeto, para garantir a criação de um sistema de espaços livres de uso público, estabelecer exigências quanto à destinação e forma de uso dos espaços livres de uso privado, e desta forma alcançar um equilíbrio entre o construído e o edificado. Estamos indicando a necessidade do estabelecimento de instrumentos legais que viabilizem os projetos urbanos. Entretanto, sem ética ambiental e estética paisagística, tanto projeto quanto lei podem ser nocivos ao ambiente e à paisagem;

- que a arquitetura moderna, pela liberação do solo devido aos pilotis, é a tipologia arquitetônica mais adequada para a ocupação das encostas, tanto para a liberação de visuais na escala do pedestre, para o uso residencial, quanto para programas de uso coletivo, como as escolas.

\section{Conceitos Projetuais de Espaços Livres}

A seguir, listamos os conceitos, ou seja, as idéias de projeto a serem criadas e implementadas para garantir a obtenção de espaços livres de edificação, para usos tanto públicos quanto privados, de lazer ou conservação:

- Criar parques nos espaços junto aos corpos d'água existentes, ao longo das linhas de drenagens e nas várzeas inundáveis, em áreas tanto públicas quanto privadas, em faixas non aedificandi de dimen- 
sões proporcionais ao porte destes corpos d'água em seus períodos de cheias e com recomposição vegetal adequada a cada caso. Os rios e as planícies aluviais estão diretamente associados aos recursos de água subterrânea potencialmente abastecedoras; assim, para evitar a contaminação deve-se destinar uma franja de $60 \mathrm{~m}$ de cada lado no fundo dos vales como área non aedificandi (Laurie, p. 162 164). Este número, a nosso ver, deve variar segundo as proporçōes das áreas inundáveis, podendo receber equipamentos criteriosamente dimensionados para permitir o desfrute destas áreas, quando se tratar de áreas de espairecimento (Lyle, 1985, p. 170). O aproveitamento dos cursos d'água como um sistema natural de drenagem serve também para o controle de inundações (Lyle, 1985, p. 73). O uso adequado dos cursos d'água como sistema natural de drenagem pluvial, com recomposição da mata ciliar, pode permitir o renascimento da vida silvestre. A linearidade do sistema hidroviário sugere a criação de corredores silvestres, que podem facilitar a implantação de um sistema de parques que tire o melhor proveito das qualidades cênicas e ambientais destas margens (Spirn, 1995);

- criar parques de conservação do patrimônio natural e da biodiversidade em que houver a possibilidade de manutenção ou a multiplicação de ecossistemas;

- delimitar as áreas cobertas de matas nativas, a serem destinadas à conservação, mas passíveis de serem ocupadas com baixíssimos índices de urbanização: densidades, taxas de ocupação e índices de aproveitamento;

- reservar os divisores de bacias, quando amplos, as ombreiras e os promontórios, a serem preferencialmente destinados ao uso público, devido ao caráter estratégico de mirantes que estas morfologias possuem;

- criar mirantes em pontos privilegiados das encostas, como promontórios e ombreiras;

- criar sistema de praças de topo conectadas por vias sobre os divisores de água. Essas vias serão determinadas segundo as declividades naturais do terreno, para a circulação de automóveis ou de pedestres; utilizando-se de escadarias, elevadoras e outros elementos alternativos para conectar os diferentes níveis;

- criar praças com escadarias, rampas, patamares e outras formas de ligação de planos em níveis diferentes; 
- criar malhas de fundo de vale com vias que bordejem os parques criados ao longo das linhas de drenagens;

- criar vias panorâmicas que acompanhem a linha d'água de lagoas e praias a uma distância tal que permita a destinação de espaços livres ambientalmente comprometidos e paisagisticamente tratados entre a orla e a via em questão;

- nos terrenos com declividades inferiores a $30 \%$, sem bosque, criar preferencialmente uma tipologia de ruas em ziguezague (oblíquas às curvas de níveis), fazendo as conexões entre as vias sobre divisores e as vias de fundo de vale; destinando $30 \%\left(3.000 \mathrm{~m}^{2}\right.$ por hectare) da área total para os espaços livres públicos, sendo que a metade deve ser de área plantada e nõo-impermeabilizada. Estabelecer lotes a partir de $220 \mathrm{~m}^{2}$, que poderão ser ocupados em até $50 \%$, e construídos com índice de aproveitamento igual a um, respeitando os recuos de frente, de fundo e em uma das laterais. Embora o reflorestamento seja sempre a solução mais econômica para a contenção de encostas, optamos pela solução descrita sempre que a área for adequada à ocupação e já estiver desflorestada, pois a urbanização não é um fato negativo, pois faz parte do ecossistema humano (Laurie, 1983, p. 162-164). Nas encostas, em geral, e, em particular, nos terrenos em que são adotadas as ruas oblíquas à topografia, a exigência de espaços públicos é muito maior do que para outras situações, porque os caminhos curvos são muito mais longos do que os retos, dissipando uma enorme quantidade de área útil. Portanto, se quisermos manter as densidades máximas de 30 domicílios por hectare, os lotes serão os menores previstos neste estudo. As ruas em ziguezague também favorecem a dissipação da velocidade das águas superficiais em dias de chuva;

- nos terrenos com declividades entre 30 e $45 \%$, sem bosque e com assentamentos consolidados, criar, sempre que não esteja sobre linha de drenagem, a tipologia de "ruas" perpendiculares às encostas (perpendiculares às curvas de níveis); destinar $40 \%$ (4.000 $\mathrm{m}^{2}$ por hectare) da área total para os espaços livres públicos, sendo que a metade deve ser de área plantada e não-impermeabilizada; a gleba poderá ser parcelada com lotes a partir de $220 \mathrm{~m}^{2}$, assentados preferencialmente a meia-encosta, com a construção de apartamentos nos lotes maiores, aproveitando o escalonamento do terreno; taxa de ocupação de $70 \%$, índice de aproveitamento 1,8; recuo de fundo e uma lateral. Igualmente neste caso, embora o reflorestamento seja sempre a solução mais econômica para a contenção de encostas, optamos pela solução descrita sempre que a área for 




Figura 6: Rua Lombard, San Francisco, CA

A rua Lombard, que possui 27 graus de declividade, é uma alternativa de projeto bastante atraente para as encostas, por mesclar soluçōes para o trânsito de automóveis, o caminho de pedestres, o acesso aos automóveis e o tratamento paisagístico do espaço público urbano, pelo plantio de espécies arbustivas, arvoretas e floríferas Fonte: Fotos da autora, 1996

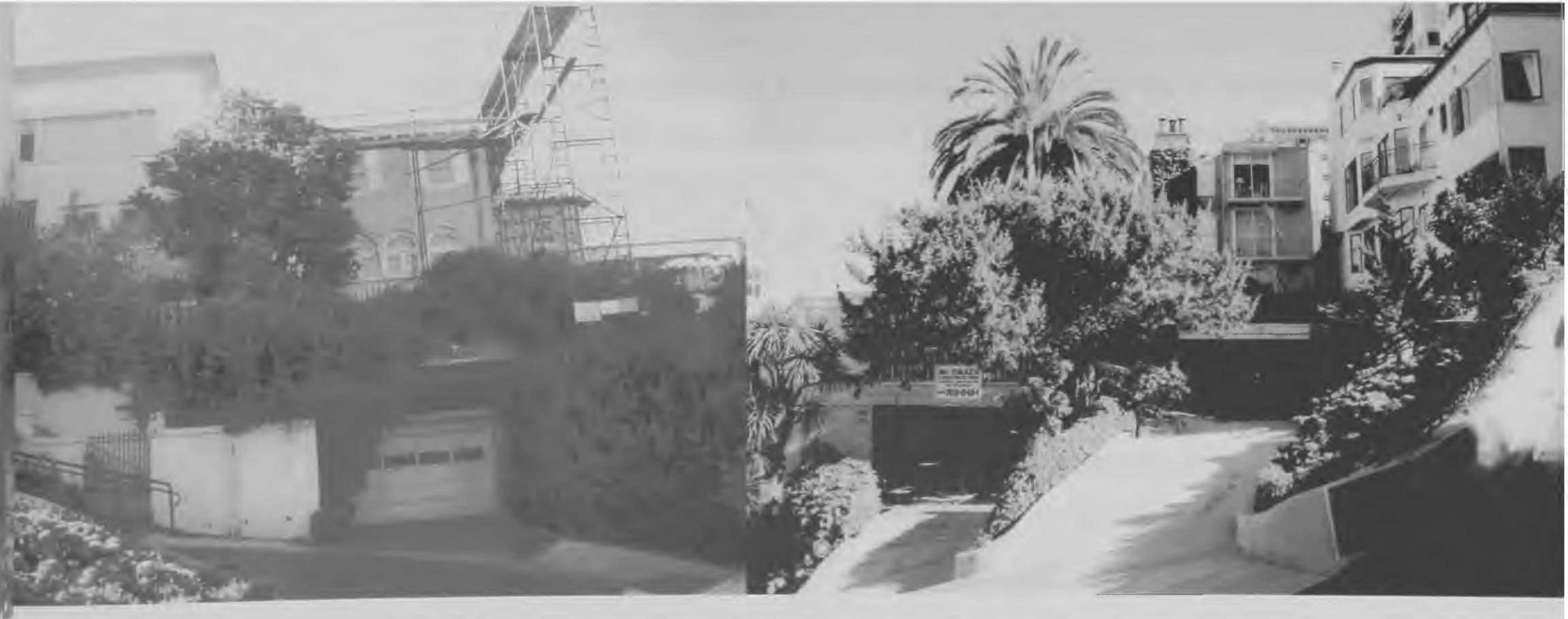

São Paulo n. 14 p. 43 - 78 - dez. 2001 
- nos terrenos com declividades superiores a $45 \%$, com ou sem bosque, adotar o uso preferencialmente residencial, de baixa densidade, ou seja, dois domicílios por hectare, destinando $20 \%$ (2.000 $\mathrm{m}^{2}$ por hectare) da área total para os espaços livres públicos, sendo que a metade deve ser de área plantada e não-impermeabilizada; lotes mínimos de $4.000 \mathrm{~m}^{2}$, taxa de ocupação de $8 \%$, índice de aproveitamento de 0,16 ;

- permitir a verticalização nos terrenos sem bosque, com declividades inferiores a $15 \%$ com o objetivo de conseguir mais espaços livres para os moradores e mais arborização, na seguinte proporção: $6.000 \mathrm{~m}^{2}$ de espaço livre privado e $3.000 \mathrm{~m}^{2}$ de espaço livre público, sendo que a metade deve ser de área plantada e nãoimpermeabilizada, 10\% de taxa de ocupação: 0,67 de índice de aproveitamento; seis pavimentos sobre pilotis e dois subsolos para garagens. Programas que demandam grandes áreas de estacionamento também deverão ficar restritos aos terrenos com declividades inferiores a 15\%, algo como o Parque Guinle, projetado originalmente por Lúcio Costa, com densidade aproximada de 30 domicílios por hectare, seis torres de seis pavimentos em aproximadamente seis hectares, com programas complementares ocupando parte do pavimento térreo. Considera-se esta uma opção amena para os padrões de densidade do urbanismo moderno, mas não podemos nos esquecer que como foi pensada para a ocupação de encostas, devido à sua complexidade, demanda uma quantidade de espaços livres para circulação maior do que as áreas planas. As superquadras de Brasília possuem densidade média de 77 domicílios por hectare $(11$ torres de cinco andares mais equipamentos), enquanto a Unidade de Habitação de Marselha, projetada por Le Corbusier em 1945, possui 84 domicílios por hectare, 1.800 habitantes em um único edifício de 18 pavimentos, incluindo equipamentos (Spreiregen, s/d. p. 245-252);

- aproveitar caminhos e trilhas de pedestres existentes na criação dos novos espaços livres públicos;

- criar parques de preservação da herança cultural em torno de sítios, dos edifícios isolados ou dos monumentos de apelo histórico e cultural;

- em se tratando do Hemisfério Sul, aproveitar as orientações leste, norte, oeste e sul, na correta implantação de atividades urbanas de média e longa permanência, permitindo a otimização das horas de sol e sombra ao longo do ano, além do adequado aproveitamento do regime de ventos. 


\section{Construção das Unidades de Paisagem segundo as Tipologias Edificadas}

Acreditamos que as possibilidades de parcelamento para os terrenos das encostas que definimos anteriormente podem gerar unidades paisagísticas satisfatórias, preferencialmente quando ocupadas com as seguintes tipologias edificadas:

1 - Unidade de paisagem com habitações de seis pavimentos sobre pilotis, mais dois pavimentos de garagem semi-enterrado, predominantemente horizontais, assentadas sobre pilotis, nos padrões dos edifícios Bristol, Nova Cintra e Caledônia (Xavier, 1991, p. 67) no Parque Guinle, Rio de Janeiro; implantadas em terrenos de um hectare, nas encostas suaves de $0-15 \%$ de declividade. Esta unidade de paisagem se compõe da somatória de uma destas unidades de habitação a cada hectare, configurando um parque, entendido este como sendo formado pelas faixas non aedificandi das drenagens existentes no terreno, convenientemente arborizadas, aproveitadas para compor a porcentagem de áreas verdes públicas, além dos demais espaços de circulação e lazer, tanto públicos quanto condominiais. Estamos considerando o habitar em seu conceito ampliado, admitindo outras funções ligadas ao cotidiano dos habitantes, como padarias, lavanderias, rotisserias, academias, pequenos auditórios, etc. Um exemplo paulista de emprego desta tipologia é o condomínio formado pelos edifícios Guarapari e Hicatu, projetados por Kneese de Mello, na Vila Mariana.

II - Unidades de paisagem com habitações de dois a três pavimentos, implantadas em lotes a partir de $220 \mathrm{~m}^{2}$ (permitindo lotes maiores), em terrenos com declividades inferiores a $45 \%$. Mesmo no caso dos lotes com pequenas dimensões, sempre deverá existir a exigência de recuos frontais e laterais ajardinados em $50 \%$, implantados em ruas em ziguezague, arborizadas em pelo menos uma das calçadas; permitindo, ao longo de uma sequência de hectares, que a unidade de paisagem se caracterize como sendo de colinas uniformemente arborizadas e edificadas, em uma trama mista de granulação, entre média e miúda. Entre os exemplos de grande porte desta tipologia, com habitações em meio a grandes jardins, citamos as residências da arquiteta Lina Bo Bardi, de 1951, e a do arquiteto Joaquim Guedes, construída em 1971, ambas no Morumbi (Xavier, 1983; Acayaba, 1986). Como exemplo de pequeno porte, citamos as residências mais abastadas de parte dos bairros operários de Vila Maria, Tucuruvi, Vila Mariana, Lapa e Pinheiros. 


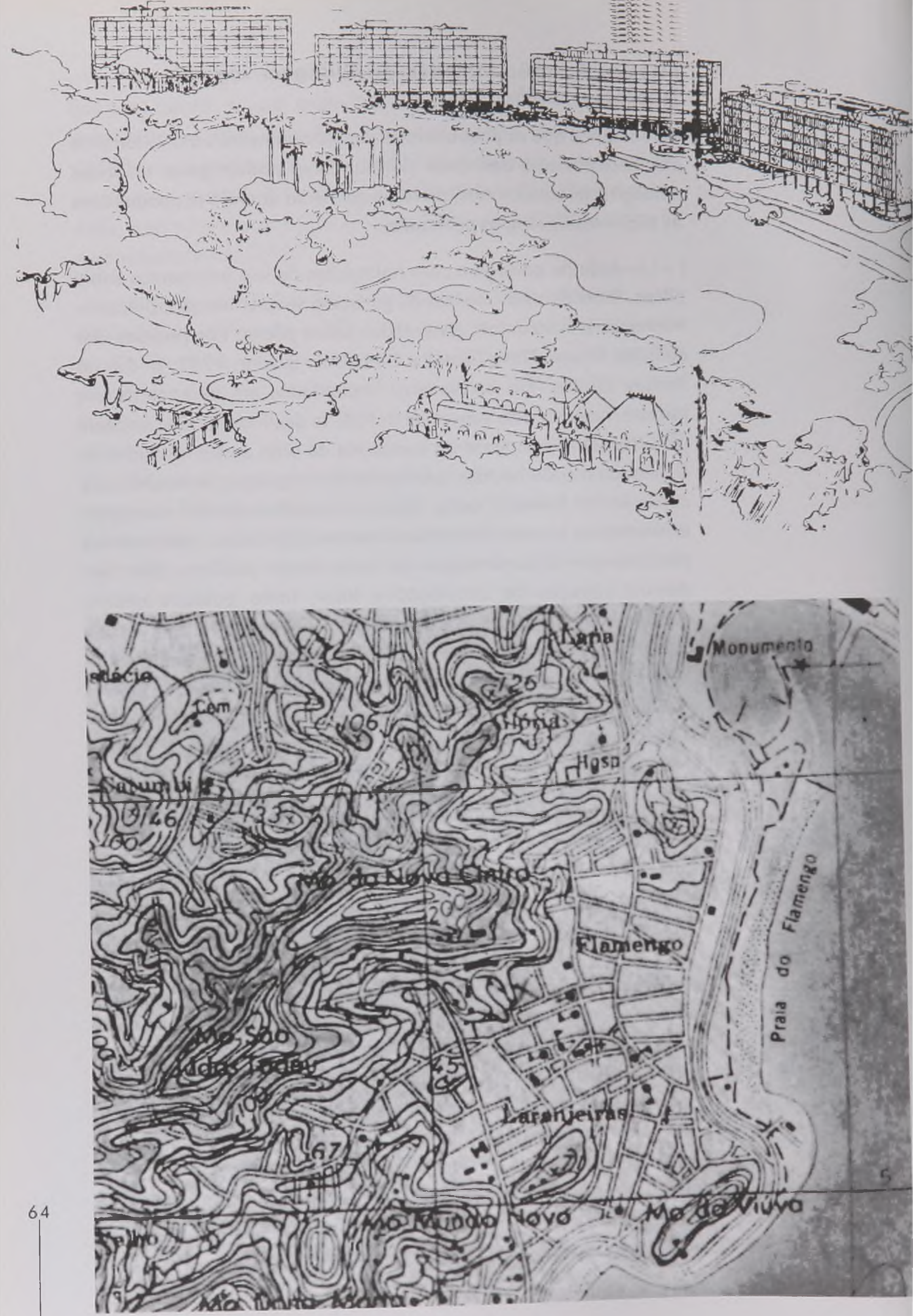



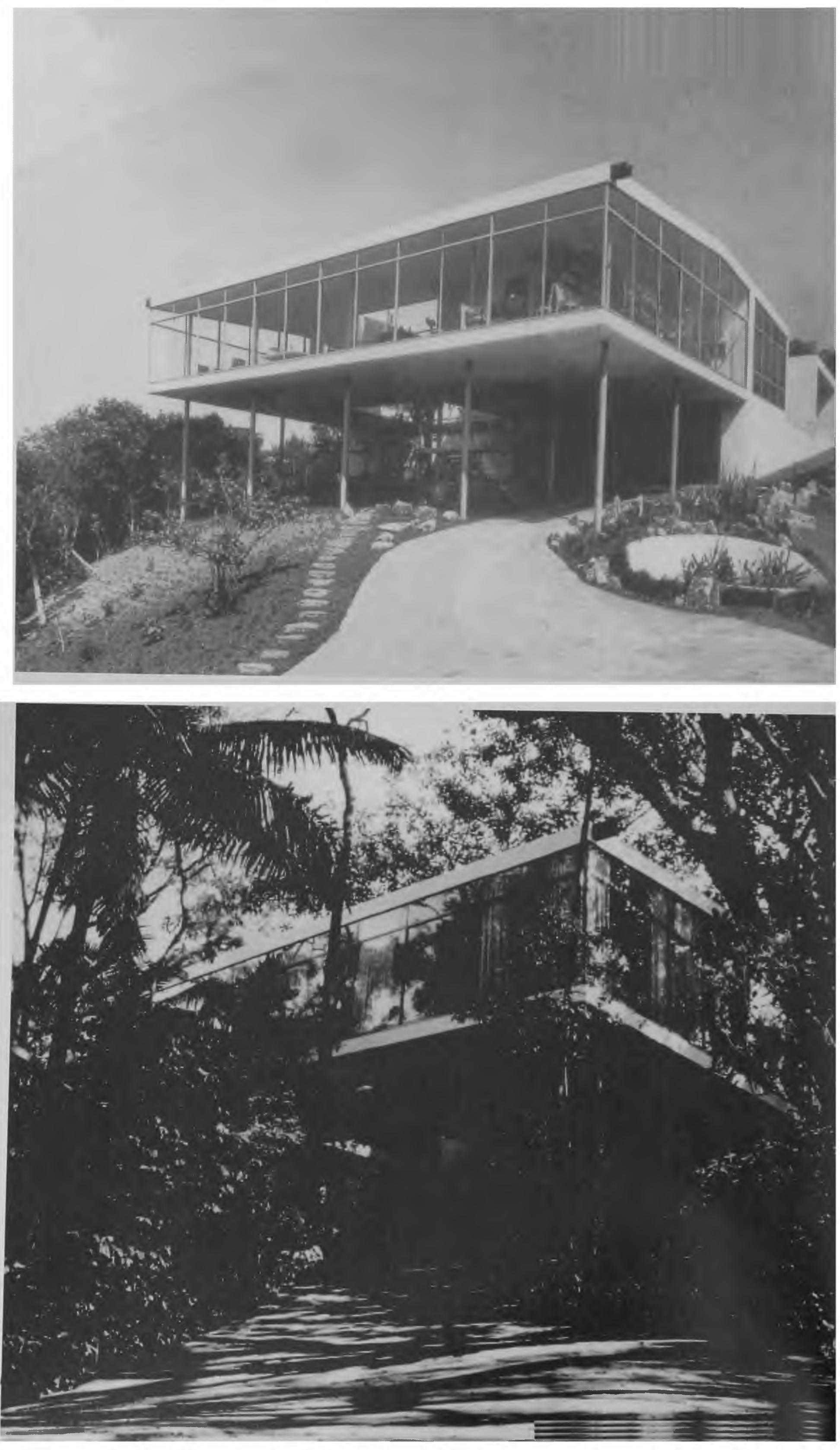

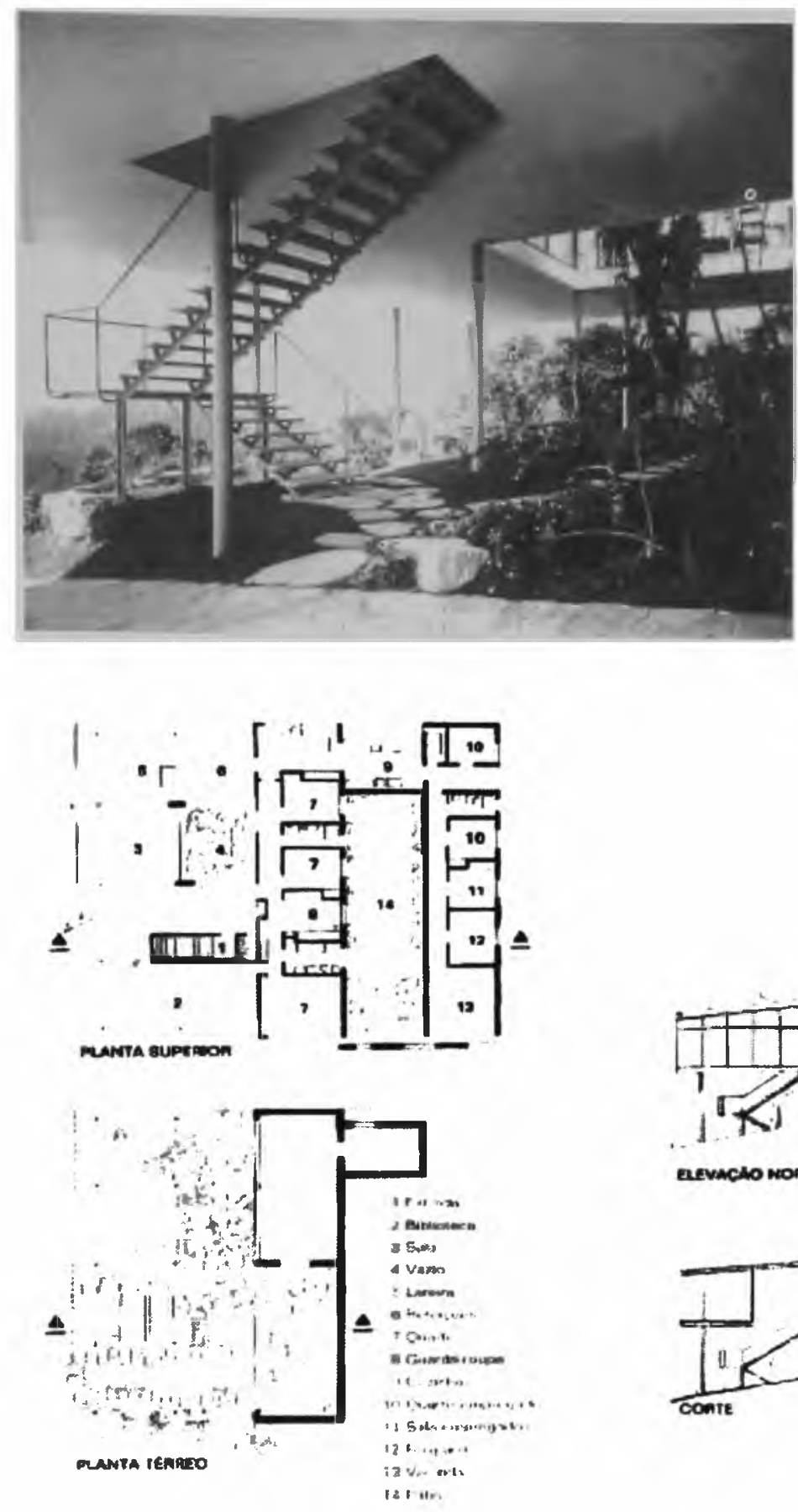

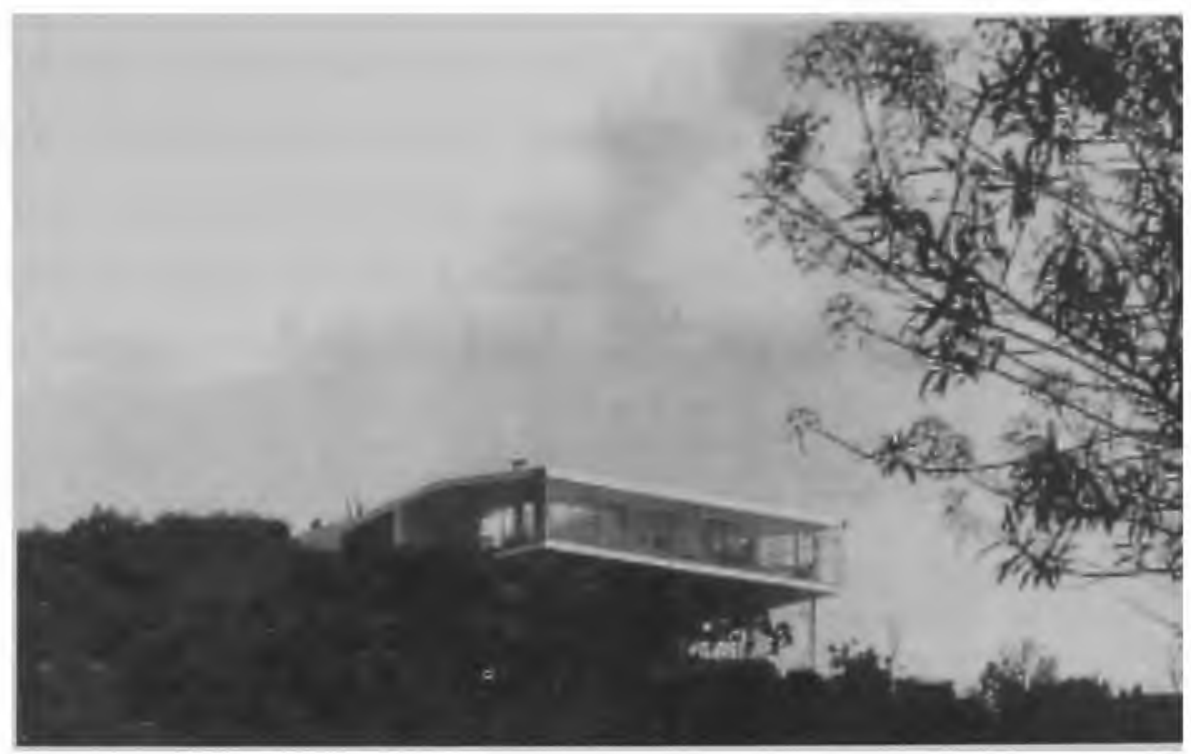

Vista da casa a partir da rua General Almérico de Moura, 1951.
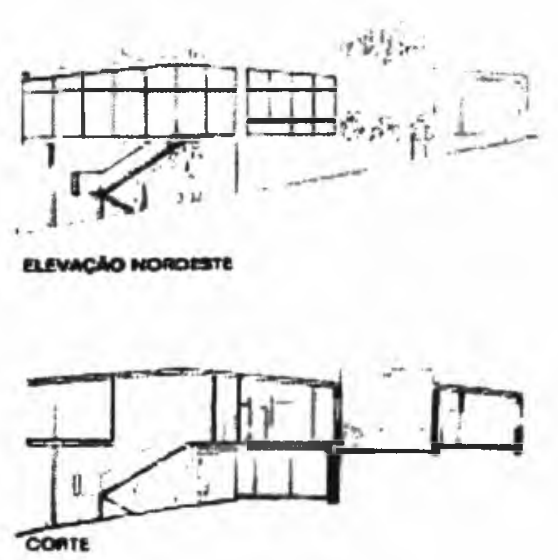

Figura 8: Paisagem da preservação - Casa de Vidro, Lina Bo Bardi, 1951

A casa de vidro, projetada por Lina Bo Bardi, tem $817,39 \mathrm{~m}^{2}$ de área construída em um terreno de $9.000 \mathrm{~m}^{2}$, taxa de ocupação igual a $4,98 \%$ (Acayaba, 1986). 0 modelo da estrutura dominó de Le Corbusier, adaptado à situação das encostas das colinas do Morumbi, é bastante adequado por permitir o domínio da paisagem, praticamente sem transformar o perfil do terreno em que está implantada

Fonte das ilustraçōes: Instituto Lina Bo e Pietro Maria Bordi, 1993

III - Unidades de paisagem com habitações de dois a três pavimentos, escalonadas, implantadas em terrenos com declividades entre 30 e 45\%, como nas ladeiras da cidade de São Francisco, Califórnia; em especial na rua Lombard. Este tipo de construção, recomendado para lugares sujeitos a terremotos, pelo emprego de materiais leves e flexíveis, é muito apropriado para a ocupação de encostas íngremes. Após a destinação de $40 \%$ ( $4.000 \mathrm{~m}^{2}$ por hectare) da área total para os espaços livres públicos, a gleba poderá ser parcelada com lotes a partir de $300 \mathrm{~m}^{2}$, com a construção de até três apartamentos nos lotes maiores, sobre o alinhamento frontal, aproveitando o escalonamento do terreno para a liberação de visuais pelos terraços; taxa de ocupação de $70 \%$, índice de aproveitamento de 1,8; recuo de fundo e uma lateral. Estas residências se encontram geralmente construídas sobre o alinhamento, ao longo de ruas perpendiculares à encosta (curvas de níveis). A maioria das casas tem a dimensão 
longitudinal do lote implantada ao longo da topografia (curvas de níveis). Das fachadas laterais se desfruta de visuais desimpedidos devido à implantação escalonada e ao respeito à legislação que proíbe a construção em altura superior às aberturas dos lotes a montante. Pode ocorrer um pequeno jardim na frente, mas o mais comum é que exista um jardim nos fundos, formando uma área verde no miolo da quadra. Em São Francisco, as residências mais antigas são geralmente de madeira e cobertas por telhados com diferentes formas; enquanto nas casas mais recentes, geminadas ou projetadas para abrigar diversos apartamentos, as coberturas são planas e servem como terraços. O que poderia parecer um excesso de densidade de construção é minimizado pela ocorrência de quadras inteiras livres de construção em meio a estes conjuntos edificados, proporcionando a criação de praças como a Alta Plaza, em Pacific Heights e Alamo Square, no Centro Cívico, em San Francisco, CA, onde a largura das ruas, as calçadas arborizadas e os amplos setores luminosos de céu também permitem este alívio visual. No Brasil, um exemplo deste tipo de ocorrência é a praça Horácio Sabino, no bairro de Pinheiros, em São Paulo, SP.

IV - Unidade de paisagem com habitações de dois a três pavimentos, implantados em meio a lotes de $4.000 \mathrm{~m}^{2}$, em terrenos com declividades superiores a $45 \%$, nos padrōes das residências do arquiteto Marcos Acayaba, que imitam uma grande árvore construída, em meio a outras árvores verdadeiras. $O$ arquiteto Marcos Acayaba pesquisou um tipo de construção para encostas íngremes, parecido com uma casa na árvore, ou parecendo uma ávore. Segawa chamou a este método criado pelo arquiteto de "ensaios de um teorema": terreno fortemente inclinado; vegetação como forma de contenção do solo; poucas e profundas fundações; planta em malha geométrica; uso de madeira, aço e concreto na estrutura; pré-fabricação; poucos pontos de apoio; visuais, a escoIher (Segawa, 1996). Estas unidades de paisagens compostas por edifícios monoestruturais construídos em meio a bosques podem ser obtidas da seguinte forma: após a destinação de $20 \%\left(2.000 \mathrm{~m}^{2}\right.$ por hectare) da área total para os espaços livres públicos, a gleba de $10.000 \mathrm{~m}^{2}$ poderá ser dividida em lotes de $4.000 \mathrm{~m}^{2}$, com a construção de $640 \mathrm{~m}^{2}$ em meio a $3.680 \mathrm{~m}^{2}$ de terrenos totalmente arborizados (taxa de ocupação de $8 \%$, índice de aproveitamento de $680,16)$. As características naturais do terreno seriam preservadas pela manutenção de sua geometria e da recomposição vegetal por espécies nativas. 

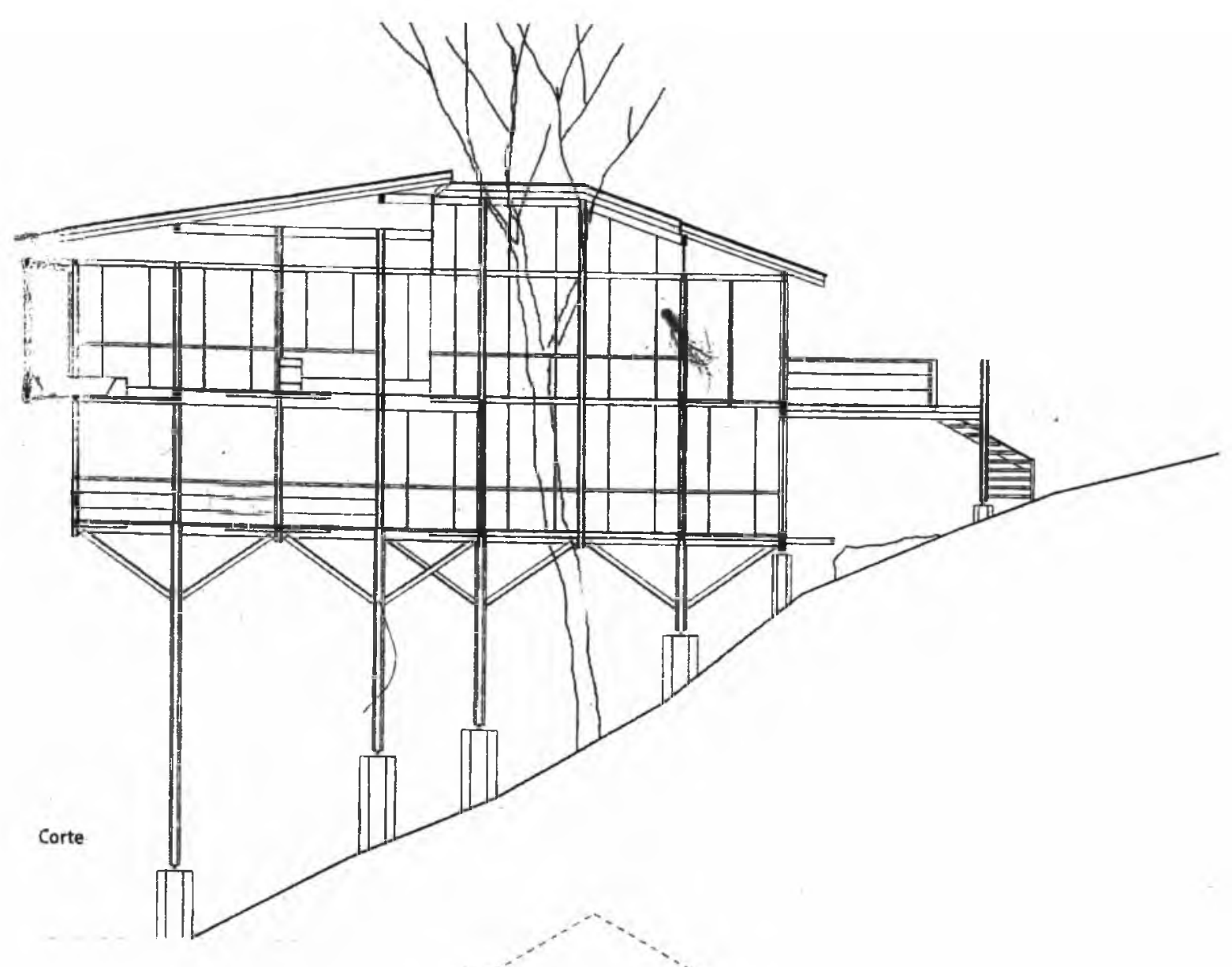

Figura 9: Paisagem da preservação - Casas de Marcos Acayaba

A casa em questão apresenta uma estrutura de poucos apoios ainda mais integrada ao sítio do que à Casa de Vidro de Lina Bo Bardi, especialmente se considerarmos que se trato de um terreno muito mais acidentado. $O$ resultado chega a ser um mimetismo entre casa e árvore, atendendo ao objetivo de ocupar as encostas ingremes, interferindo o mínimo possivel no componente paisagístico Fonte das ilustrações: Segawa, 1996
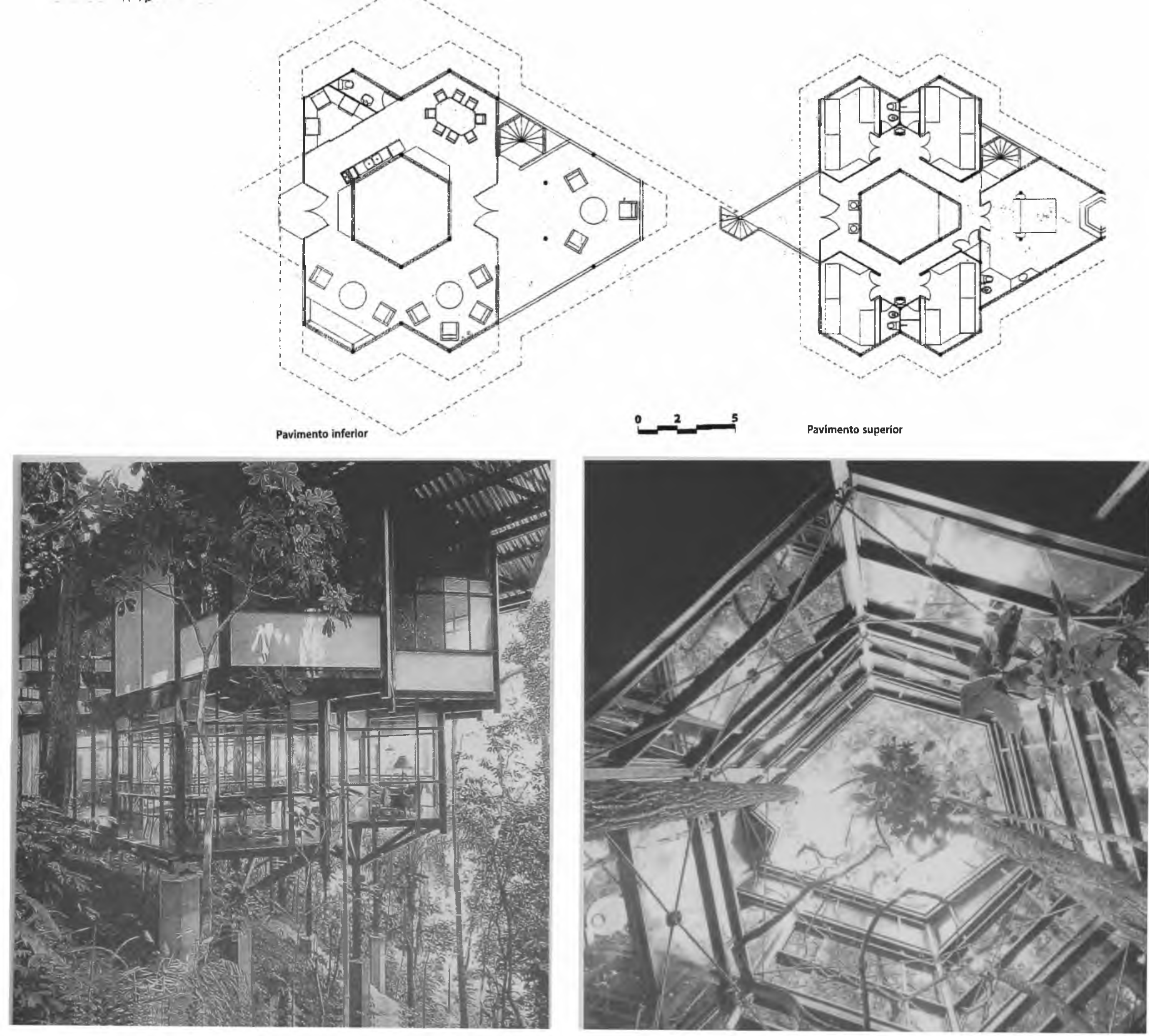
$V$ - Complementação e interligação das unidades de paisagem com elementos de circulação de automóveis e pedestres, atendendo às características dos terrenos das encostas:

a) construção de malhas ortogonais, completadas por escadarias e rampas em pontos estratégicos no alto dos morros.

Como exemplo citamos as escadarias do Santuário do Bom Jesus, em Braga, Portugal; o Santuário de Bom Jesus de Matosinhos, em Congonhas do Campo, MG; e a Igreja de Nossa Senhora da Glória, no Rio de Janeiro, RJ; reservando algumas quadras para praças e pequenos parques: as ruas Lombard, Filbert e Greenwich em São Francisco, CA; as ruas Cristiano Viana e Alves Guimarães, em São Paulo, SP; e as ruas Monsenhor Topp e José Boiteux, em Florianópolis, SC;

b) construção de malhas sinuosas (cujas vias não ultrapassem 15\% de declividade) em ziguezague, nos terrenos com declividades naturais entre 15 e $45 \%$, buscando interligar os diferentes níveis, dando acesso aos automóveis.

Como exemplo citamos a malha dos bairros de Vila Maria Alta, Morumbi, Pacaembu, Alto da Lapa e Alto de Piheiros em São Paulo, SP;

c) criação de praças mirantes nos pontos estratégicos, como as saliências de terreno conhecidas como ombreiras. Como exemplos não-rituais desta solução, repleta de escadarias e rampas propícias ao espetáculo urbano, citamos: a ladeira da Memória e a praça Ramos de Azevedo, no centro de São Paulo, SP; a praça Wendell Wikie, entre o Pacaembu e as Perdizes; e a praça Diogo do Amaral, na Lapa, em São Paulo, SP.

São exemplos romanos desta solução: o belvedere da Colina Pinciana, sobre a Piazza del Popolo e a escadaria da Piazza de Spagna. São exemplos semelhantes, mas em escala ampliada: o Santuário do Bom Jesus de Braga, em Portugal; o Santuário de Bom Jesus de Matosinhos, em Congonhas do Campo, MG; e o Santuário de Saint-Joseph du Mont-Royal, em Montreal, no Canadá. Em escala singela, temos na cidade do Rio de Janeiro a lgreja de Nossa Senhora da Glória do Outeiro;

d) construção de vias sobre divisores e praças de topo para o desfrute de visuais, explorando textura e geometria adequadas na elaboração dos pavimentos. 
O exemplo clássico de praça de topo é o Campidoglio, em Roma, conhecido como o "Caput Mundi". Entretanto, existe uma contradição: o terreno outrora irregular foi transformado em calota abaulada para servir de base para a pavimentação com mármores negro e branco, na forma de uma rosácea com 12 pontas inserida em uma figura oval. Trata-se, na verdade, de um falso topo, com a impermeabilização de uma linha de drenagem, fato desaconselhável em termos de conservação. O local em que hoje se encontra a Piazza do Campidoglio (fortaleza de uma cidade), originalmente era um talvegue, entre a colina Capitolina (onde estava o Templo de Júpiter) e a Ars (arsis, elevação; ou arce, fortaleza; ou arci, primeiro elemento), local do antigo templo de Juno, onde hoje está a lgreja de Santa Maria de Aracoeli. As duas pequenas colinas foram ligadas para a construção do Tabularium (arquivos públicos do século $1^{\circ}$ a.C., por Lutácio Catulo), que hoje abrigam a prefeitura da cidade de Roma. O piso aparece em gravuras do século 16 , mas só foi construído conforme hoje se encontra em 1940 (Argan \& Contardi, 1940; Bacon, 1995; Garolla Ed., 1985);

e) construção de vias em binário ou falso binário, marginais às faixas non aedificandi de rios e córregos, transformadas em praças e mesmo em grandes parques urbanos. Como exemplo citamos as vias que contornam as seguintes praças e parques paulistanos: Vinícius de Morais e Alfredo Volpi, no Morumbi; Centro Educacional Thomaz Mazzoni, na praça Cianorte na Vila Maria; praça Dolores Ibarruri "La Passionaria", ao longo do Ribeirāo das Corujas, em Pinheiros;

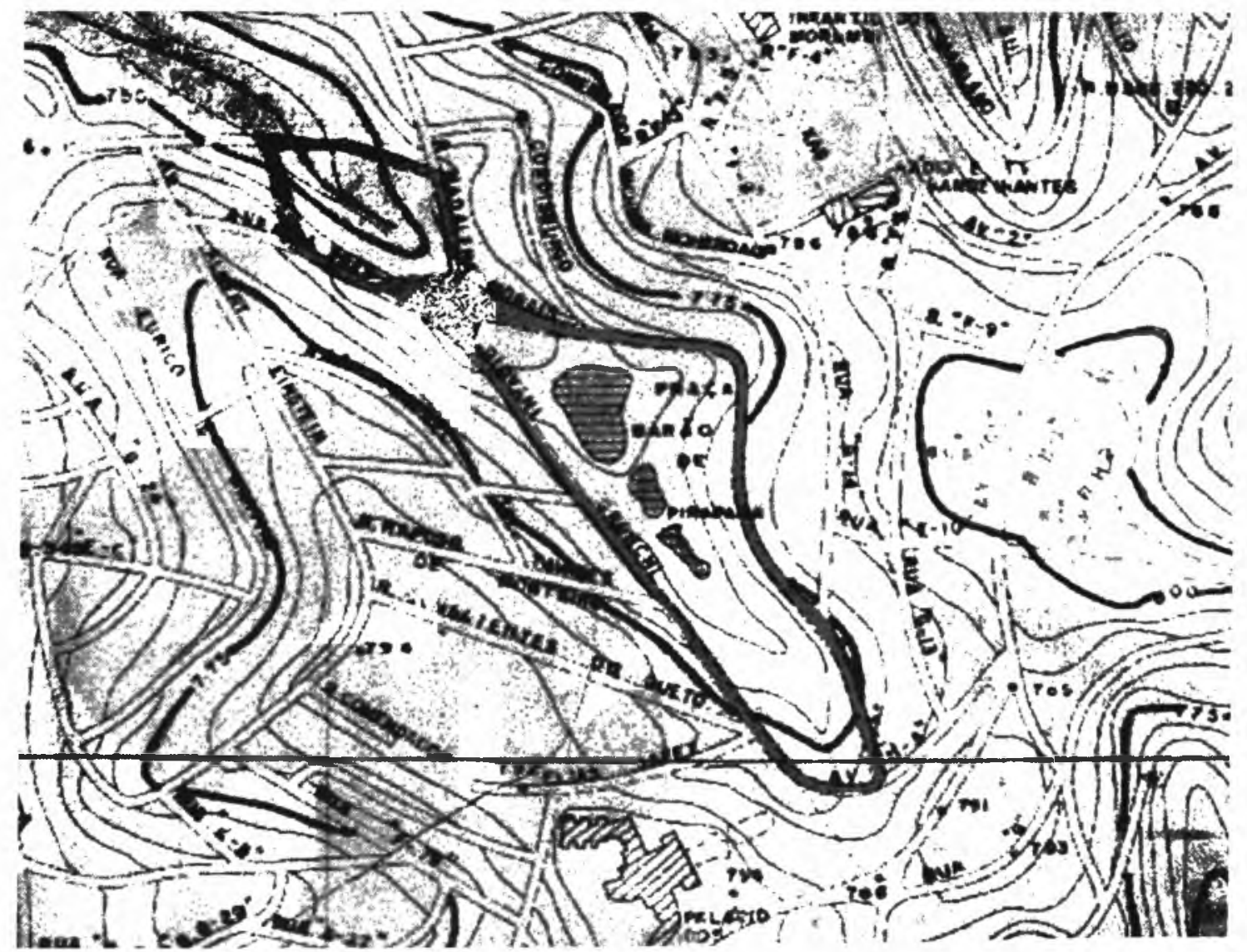


f) construção de grandes e pequenas pontes para vencer as superfícies aquáticas, em substituição aos aterros de tubulóes e manilhas e de acordo com o porte da linha de drenagem e o uso estipulado, seja ele o tráfego de pedestres ou de veículos, adequando-as às necessidades ambientais e explorando os valores paisagísticos. Como exemplo citamos as mais diversas pontes existentes desde a Antiguidade romana e algumas soluções atuais bem-sucedidas existentes nas cidades turísticas, especialmente para servir aos pedestres;

g) construção de vias panorâmicas que explorem os visuais proporcionados pelos desníveis naturais dos terrenos em questão. Como exemplo citamos as vias de contorno: do José Mendes, em Florianópolis; entre o centro e a Barra, em Salvador; a via costeira Amalfitana, na ltália; e a via das 17 milhas, na Califórnia;

h) construção de meios alternativos de transporte público em terrenos muito íngremes. Como exemplo citamos o Elevador Lacerda e o Plano Inclinado, em Salvador; os bondes, elevadores e funiculares de Lisboa; os bondes de São Francisco, de Santa Teresa e do Corcovado; os funiculares de Quebec; e os caminhos aéreos do Rio de Janeiro, Camboriú, Istambul e Santorini.

$\mathrm{VI}$ - Identificação e realce das unidades de paisagem por meio da implantação de edificações emblemáticas, com formas diferenciadas e atendendo a usos variados, localizadas nos pontos estratégicos das encostas, preferencialmente nos topos e nas ombreiras. Nestes pontos, normalmente, estão localizadas as edificações emblemáticas de caráter histórico a serem valorizadas e protegidas da agressão que os automóveis e a verticalização proporcionam, pela criação de espaços livres que permitam o distanciamento necessário para observá-las integralmente ov em ângulos selecionados, respeitando suas dimensões horizontais e verticais. Existem novos usos e atividades que podem ser atendidos por meio da construção de novas edificações emblemáticas. Estas construções, obrigatoriamente, devem procurar lugares estratégicos para serem colocadas e, portanto, não podem ser resolvidas pela edificação desqualificada e desprovida de significado simbólico para o coletivo.

Estruturas como as torres de telecomunicaçōes, que obrigatoriamente têm sido colocadas nos pontos culminantes dos morros, devem ter algo mais a oferecer, além de seus serviços. As antenas são um mal necessário quando agridem a paisagem e impedem o uso de um lugar público. Mas elas podem ser simplesmente um bem, uma unidade emblemática. O Morro do Corcovado tem apelo 
unicamente turístico, pois as torres de telecomunicações da cidade do Rio de Janeiro estão no vizinho Morro do Sumaré. A colina do Telégrafo, em São Francisco, CA, tem uma utilidade turística de fundo histórico, pois foi aproveitada na criação de um museu, enquanto as demais antenas que existem na cidade estão apoiadas na Torre Sutro, distantes do centro. O Empire State Building abriga antenas de oito emissoras de rádio e TV no topo de sua torre e a Tour Eiffel, de forte apelo turístico, além das antenas de TV, possui equipamentos de um laboratório meteorológico no alto de sua torre. Com o desenvolvimento da TV a cabo (multicanais com freqüências muito curtas, microondas, sistemas digitais e torres muito próximas) e das transmissões via satélite, as transmissoras deverão buscar formas mais qualificadas para diminuir o volume de suas instalaçōes, liberando para o uso público muitos dos espaços que hoje ocupam.

\section{Conclusões}

Assim como os estudos urbanísticos nos levaram a ver a cidade como parte da natureza, ou seja, como sendo necessária à sobrevivência dos seres humanos, os avanços da área tecnológica permitiram que muitos dados cartográficos, imagens de satélite e bancos de dados pudessem ser informatizados, no sentido de facilitar e agilizar as análises e conseqüentes propostas rurais e urbanas. Do mesmo modo, assim como as pesquisas em arquitetura detectaram algumas tipologias mais apropriadas à ocupação dos terrenos das encostas dos morros e dos vales dos rios e as pesquisas em desenho urbano e paisagismo detectaram a necessidade de associar espaços livres e vegetados às taxas de ocupação e índices de aproveitamento propostos, o uso da computação gráfica permitiu visualizar a realidade existente, testar planos diretores municipais, criar e simular novos padrões de arquitetura e urbanização apropriados à paisagem de encostas. A continuidade deste trabalho demanda a informatização dos dados cadastrais e relacionais, a serem trabalhados em Sistema de Informações Geográficas - SIG e Projeto auxiliado pelo Computador-CAD, de modo a testar as hipóteses aventadas por meio da simulação e animação de alternativas, conforme estudos que já vêm sendo elaborados contemporaneamente. 


\section{Bibliografia}

ACAYABA, Marlene Milan. Residências em São Paulo 1947-1975. São Paulo: Projeto. 1986.

AFONSO, Sonia. Urbanização de encostas. A ocupação do Morro da Cruz. Florianópolis. SC. São Paulo, 1992. Dissertação (Mestrado) - Faculdade de Arquitetura e Urbanismo, Universidade de São Paulo, 376 p.

- Urbanização de encostas. A ocupação do Morro da Cruz. Florianópolis. SC. Trabatho Programado 2. São Paulo: FAUUSP, 1992. 112p.

- Urbanização de encostas: Crises e possibilidades. O Morro da Cruz como um referencial de projeto de arquitetura da paisagem. São Paulo, 1999. Tese (Doutorado) - Faculdade de Arquitetura e Urbanismo, Universidade de São Paulo. 645p.

ARGAN, Giulio C., CONTARDI, Bruno. Michelangelo architetto. Milão: Electa, 1940.

ATS/FPe. 1993. Roma como fue y como es. Con reconstrucciones de los monumentos de la Roma Antigua. Roma: Ediciones Vision, 1962.

BACON, Edmund. Design of cities. Londres / Nova York: Thames \& Hudson. 1995 (1967).

CLERGEAU, Philippe. Urban biodiversity: Is there such a thing? Le courrier du CNRS, n. 82, p. 102 104, 1996. Ingénieur à l'INRA, chercheur à l'unité Fonctionnement des écosystèmes et biologie de la conservation (URA 1853 CNRS), Université Rennes I, avenue du Général Leclerc, 35042 Rennes Cedex. http://193.55.107.3/pirvil/clergeau.htm.

COSTA, Lúcio. Lúcio Costa: Registro de uma vivência. São Paulo: Empresa das Artes, 1995.

DOURADO, Guilherme Mazza (Org.). Visões de paisagem. Um panorama do paisagismo contemporâneo no Brasil. São Paulo: Associação Brasileira de Arquitetos Paisagistas - ABAP, 1997.

GAROLLA, ED. Capitoline Museums. Rome Guide, n. 5. Milão: Federico Garolla Editore, 1985.

FATOR GIS. Site especializado em Sistema de Informaçōes Geográficas htttp://www.fatorgis.com.br.

GUEDES JR., Alexandre. Mapeamento hidrogeológico da ilha de Santa Catarina utilizando geoprocessamento. Florianópolis: UFSC, 1999.

LAURIE, Michael. Introducción a la arquitectura del paisaje. Barcelona: GG., 1983. p. 162-164.

LYLE, John Tillman. Design for human ecosystems. Landscape, land use and natural resources. Washington/Covelo: Island Press. 1999 (versão anterior utilizada Van Nostrand, 1985).

MACEDO, Silvio S. Paisagem e habitação verticalizada. Os espaços livres como elementos de desenho urbano. São Paulo, 1988. Tese (Doutorado) - Faculdade de Arquitetura e Urbanismo, Universidade de São Paulo.

McHARG, Ian L. Design with nature. Nova York: John Wiley \& Sons, 1992.

MORETTI, Ricardo de S. Loteamentos: Manual de recomendações para a elaboração de projetos. São Paulo: IPT, 1986.

PEREIRA, Alice T. Cybis (Ed.) COINFA 98 - I CONFERÊNCIA LATINO-AMERICANA DE INFORMÁTICA NO ENSINO DA ARQUITETURA E IV SEMINÁRIO NACIONAL DE INFORMÁTICA NO ENSINO DE ARQUITETURA. 1998. Florianópolis, SC. Anais. Florianópolis: ERG/ARQ/UFSC.

REGO NETO, Cândido B., ROSA FILHO, Octacílio da. Carta geotécnica das encostas do perímetro urbano de Florianópolis. Morro da Cruz. Parte 1. Florianópolis: Prefeitura Municipal de Florianópolis. IPUF - Instituto de Planejamento Urbano de Florianópolis / COPLAN Coordenadoria de Planos e Programas, 1986.

SEGAWA, H. As vertentes da invenção arquitetônica: Arquitetura da lógica, da beleza, onde nada sobra e nada falta, Revista Projeto e Design, n. 198, p. 34, jul. 1996. 
SPIRN, Anne W. O jardim de granito: A natureza no desenho da cidade. Tradução de Paulo Renato Mesquita Pellegrino. São Paulo: Edusp, 1995 (1984).

STEINITZ, Carl. A Framework for planning, practice and education. In: YOKOHARI, Makoto (Ed.). Process Architecture, n. 127. Tokyo: Landscape Planning. Process Architecture Co. Ltd. 1994.

Landscape design processes: Six questions in need of answers and three case studies.

Roteiro da palestra apresentada ao III ENEPEA. São Carlos. out. 1996, 22p.

STEINITZ, Carl (Ed.) Alternative futures for Monroe County. Pensilvânia, Cambridge, MA. 1994. hHtp://www.gsd.harvard.edu/depts/larchdep/research/monroe.

TOLEDO, Benedicto Lima de. São Paulo: Três cidades em um século. São Paulo: Duas Cidades, 1983.

VAN LEEUWEN-MAILLET - Anne-Marie. La nature dans la ville de Rome, entre perception et usage. Les Annales de la Recherche Urbaine, n. 74, p. 59-68, mar. 1997.

XAVIER, Alberto et al. Arquitetura moderna no Rio de Janeiro. Rio de Janeiro: Rio Arte. 1991, p. 67.

(*) Este artigo foi originalmente apresentado no ENEPEA 2000 e revisado para esta publicação. A pesquisa foi elaborada para a tese de doutorado "Urbanização de encostas: Crises e possibilidades. O Morro da Cruz como um referencial de projeto de arquitetura da paisagem", orientada pelo Prof. Dr. Silvio Soares Macedo, professor titular do GDPA - Grupo de Disciplinas Paisagem e Ambiente / FAUUSP. As ilustrações deste texto também fazem parte da mesma tese. 